\title{
PENGARUH LAMA PENGERINGAN BETON SERAT PANDAN PUNDAK DURI (Pandanus tectorius) TERHADAP KUAT TARIK BELAH BETON
}

(Kajian terhadap Ukuran Agregat Maksimal 10-20 mm)

\author{
Faizal Hadi ${ }^{1)}$, Agustin Gunawan ${ }^{2)}$ \\ ${ }^{1), 2)}$ Program Studi Teknik Sipil, Fakultas Teknik, Universitas Bengkulu \\ Corresponding Author: faizalhadi@yahoo.co.id
}

\begin{abstract}
Abstrak
Beton merupakan material dengan kuat tekan yang tinggi, namun lemah terhadap kuat tarik. Kelemahan kuat tarik beton dapat diminimalisir dengan menambahkan serat pandan pundak duri. Penelitian ini bertujuan untuk mengetahui pengaruh penambahan serat pandan pundak duri terhadap kuat tarik belah beton dan mengetahui variasi persentase penambahan serat yang mengalami kuat tarik tertinggi. Penelitian ini menggunakan benda uji berbentuk silinder dengan ukuran tinggi $30 \mathrm{~cm}$ dan diameter $15 \mathrm{~cm}$ (SNI 03-4810-1998) sebanyak 32 benda uji, terdiri dari 8 beton normal dan 24 beton variasi. Penambahan serat pandan pundak duri dengan variasi 0,25\%, 0,5\%, dan 0,75\% dilakukan berdasarkan volume benda uji. Campuran adukan beton menggunakan nilai faktor air semen 0,5 dan slump 60-100 mm. Kuat tarik belah beton diuji pada umur 7 hari dan 14 hari pengeringan benda uji setelah usia 27 hari perendaman. Hasil pengujian kuat tarik belah beton dengan variasi penambahan serat pandan pundak duri menunjukkan penurunan. Penurunan kuat tarik belah beton untuk umur 41 hari menunjukkan penurunan kuat tarik belah yang lebih kecil dari beton umur 34 hari terhadap beton normal. Persentase penurunan kuat tarik belah beton terendah dan tertinggi terhadap beton normal berturut-turut sebesar 9,249\% (variasi 0,25\%, umur 41 hari) dan 14,518\% (variasi 0,75\%, umur 34 hari).
\end{abstract}

Kata kunci: beton serat, serat pandan pundak duri, kuat tarik

\begin{abstract}
Concrete is a material that have the strength to compression, but it is weak against tensile strength. The weakness of the tensile strength of concrete can be minimized by adding pandanus tectorius fiber. This study was aimed to determine the effect of adding pandanus tectorius fiber to split- tensile strength of concrete and percentage of the fiber in concrete that shows the highest split- tensile strength. The specimens used in this study is cylindrical with dimensions of $30 \mathrm{~cm}$ in height and $15 \mathrm{~cm}$ in diameter (SNI 03-4810-1998). Total of specimens is 32 that consist of 8 normal concretes and 24 variation concretes. An addition of pandanus tectorius fiber with the variation of 0,25\%, 0,5\%, and $0,75 \%$ was based on volume of the specimen. The mix design of concrete used water-cement ratio of 0.5 and slump of 60-100 $\mathrm{mm}$. The split-tensile strength of concrete was tested at 7 days and 14 days of dryng after immersing for 27 days. The result of split-tensile strength test of concrete with a variation of pandanus tectorius fiber showed a decreasing. The decreasing of split-tensile strength of concrete at 41 days was smaller than at 34 days to normal concrete. The highest decreasing percentage of split-tensile strength of variation concrete to normal concrete was respectively $9,249 \%$ (variation 0,25 tested at 41 days) and 14,518\% (variation 0,75\% tested at 34 days).
\end{abstract}

Keywords: concrete fiber, pandanus tectorius fiber, tensile strength 


\section{PENDAHULUAN}

Beton memiliki banyak kelebihan dibandingkan bahan konstruksi lainnya antara lain mampu memikul beban tekan, tahan temperatur tinggi, dan biaya yang relatif murah. Kelemahan beton adalah memiliki kuat lentur yang rendah dan sifatnya yang getas (Amna, dkk, 2014). Kelemahan beton dapat diminimalisir dengan dilakukan beberapa pengembangan beton antara lain dengan penggunaan beton serat.

Beton serat merupakan modifikasi beton konvensional dengan menambahkan serat pada adukannya (Suhardiman, 2012). Serat sintetis merupakan serat buatan yang bahan dasarnya tidak tersedia langsung dari alam. Serat sintetis antara lain serat-serat logam, polimerik, karbon, dan gelas. Serat alami merupakan serat pertama yang digunakan sebagai bahan pencampur beton dan serat alami yaitu seperti serat akwara, bambu, rami, ampas kayu, jerami, sisal, sabut kelapa, dan lain-lain (Amri, 2005).

Sifat fisik yang dimiliki daun pandan yaitu kuat tarik. Kekuatan merupakan salah satu sifat serat yang sangat penting supaya seratserat tersebut tahan terhadap tarikan-tarikan pada waktu pengolahan selanjutnya. Kekuatan tarik pandan berkisar antara 2,36,0 kg. Kekuatan dalam keadaan basah yang ada lebih rendah dari keadaan kering karena dalam keadaan kering kuat tarik yang didapat lebih besar daripada dalam keadaan basah (Winarni dan Waluyo, 2006).

Daerah pesisir memiliki banyak tumbuhan laut yang pemanfaatannya kurang digunakan, salah satunya ialah pandan pundak duri. Kandungan yang terdapat di dalam pandan pundak duri antara lain selulosa, lignin, holoselulosa, air dan serat. Kandungan tersebut selulosa berkisar 83-
88\%, lignin berkisar 18-22\%, holoselulosa berkisar 37-76\%, air berkisar 7,88-9,14\%, dan serat yang terkandung cukup tinggi (Winarni dan Waluyo, 2006).

Penelitian ini membahas mengenai pengaruh lama pengeringan beton serat pandan pundak duri terhadap kuat tarik belah beton. Peneliti kemudian memberikan perlakuan terhadap beton serat yaitu berupa lama pengeringan selama 7 hari dan 14 hari setelah 27 hari perendaman. Perlakuan pada lama pengeringan ini diharapkan untuk mendapatkan kuat tarik belah beton yang maksimal pada variasi campuran.

\section{Beton}

Beton adalah campuran yang terdiri dari semen, air, agregat kasar, dan agregat halus serta bahan tambah apabila diperlukan dengan perbandingan tertentu. Beton bersifat plastis pada saat pertama dibuat dan kemudian secara perlahan-lahan akan mengeras seperti batu (SNI 2439:2011). Struktur beton sangat dipengaruhi oleh komposisi dan kualitas bahan-bahan pencampur beton seperti yang tercampur dalam perencanaannya (Darul dkk, 2013).

\section{Semen portland}

Semen portland merupakan semen hidrolis yang dihasilkan dengan cara menggiling terak terutama terdiri atas kalsium silikat yang bersifat hidrolis dan digiling bersamasama dengan bahan tambahan berupa satu atau lebih bentuk kristal senyawa kalsium sulfat dan boleh ditambah dengan bahan tambahan lain (SNI 03-2049-2002).

\section{Agregat kasar}

Agregat kasar adalah kerikil sebagai hasil disintegrasi 'alami' dari batuan atau berupa batu pecah yang diperoleh dari industri pemecah batu dan mempunyai ukuran butir antara $5 \mathrm{~mm}$ sampai $40 \mathrm{~mm}$ (SNI 03-28472002). Agregat kasar mempengaruhi 
kekuatan akhir beton keras dan daya tahannya terhadap disintegrasi beton, cuaca, dan efek-efek perusak lainnya. Kandungan bahan organik maksimum pada agregat kasar adalah sebesar $1 \%$ dan harus mempunyai ikatan yang baik dengan semen.

\section{Agregat halus}

Agregat halus adalah pasir alam hasil disintegrasi alami batuan atau pasir yang dihasilkan oleh industri pemecah batu dan mempunyai ukuran butir maksimal $5 \mathrm{~mm}$ (SNI 03-2847-2002). Fungsi agregat halus adalah sebagai bahan pengisi dalam campuran adukan (mortar) dan beton. Batas maksimal kandungan organik pada agegat halus adalah sebesar 5\%. Syarat agregat halus dapat dilihat pada PBBI 1971.

Air

Air menurut SNI 19-6728-2002 adalah semua zat cair yang terdapat di alam dan berasal dari sumber-sumber air, baik yang terdapat di atas maupun di bawah permukaan tanah. Kekuatan dan mutu beton umumnya sangat dipengaruhi oleh jumlah air yang dipergunakan (Aulia, 2012).

\section{Serat dan beton serat}

Serat merupakan bahan tambah yang dapat digunakan untuk memperbaiki sifat-sifat mekanik beton, antara lain serat baja, serat polypropelene, serat kaca, serat asbestos, serat kevlar, serat karbon, dan serat kawat. Banyak sifat-sifat beton dapat diperbaiki dengan penambahan serat, diantaranya adalah dengan meningkatnya daktilitas, ketahanan impact, kuat tarik dan lentur, ketahanan terhadap kelelahan, dan ketahanan abrasi (Kemalasari, 2008).

Serat yang panjang dan tipis dengan rasio 1/d>100 mempunyai lekatan dengan beton yang lebih besar dibandingkan dengan serat yang pendek dengan dengan serat yang pendek dengan rasio $1 / d<50$. Hal ini berdasarkan penelitian oleh Hannant D.J, hasil percobaan untuk 1/d $<50$ menunjukkan hasil yang mudah untuk dicabut dari beton. Peningkatan aspek rasio serat akan memberikan pengaruh yang signifikan terhadap kekuatan tarik maupun lentur beton (Amri, 2005).

Beton yang diberi bahan tambah serat disebut beton serat. Beton serat menurut ACI Committee 544 diartikan sebagai beton yang terbuat dari semen hidrolis, agregat halus, agregat kasar dan sejumlah kecil serat tersebar secara acak, yang masih dimungkinkan untuk diberi bahan-bahan additive. Penambahan serat pada adukan beton dapat menimbulkan masalah pada fiber dispersion dan kelecakan adukan. Fiber dispersion dapat diatasi dengan memberikan bahan tambah berupa superplastisize atau dengan meminimalkan diameter agregat maksimum (Kemalasari, 2008).

\section{Serat pandan pundak duri}

Pandan pundak duri adalah sejenis tumbuhan serupa pandan besar anggota suku Pandanaceae. Kandungan air daun pandan pundak duri yang telah mengalami perlakuan berkisar antara 7,88\%-9,14\% dan massa jenis serat daun pandan yaitu 0,96 $\mathrm{gr} / \mathrm{cm}^{3}$ (Winarni dan Waluyo, 2006).

Kekuatan tarik serat adalah beban maksimal yang dapat ditahan oleh benda uji hingga putus. Kekuatan tarik pandan berkisar antara 2,3-6,0 kg, sedangkan pandan masyarakat memiliki kekuatan $5 \mathrm{~kg}$. Kekuatan tarik merupakan salah satu sifat serat yang sangat penting supaya serat-serat tersebut tahan terhadap tarikan pada waktu pengolahan selanjutnya. Kekuatan dalam keadaan basah lebih rendah dari keadaan kering oleh karena itu pengolahan dilakukan pada keadaan kering (Winarni dan Waluyo, 2006). 


\section{Faktor air semen}

Faktor air semen adalah angka perbandingan antara berat air bebas dan berat semen dalam beton (SNI 03-2834-2002). Peningkatan jumlah air akan meningkatkan kemudahan pengerjaan dan pemadatan, tetapi akan mereduksi kekuatan beton, menimbulkan segresi, dan bleeding (Sari, 2015).

\section{Slump}

Slump adalah suatu teknik untuk memantau homogenitas dan workability adukan beton segar dengan suatu kekentalan tertentu yang dinyatakan dengan satu nilai slump. Nilai slump umumnya meningkat sebanding dengan nilai kadar air campuran beton, dengan demikian berbanding terbalik dengan kekuatan beton (SNI 1972:2008).

\section{Kuat tarik belah beton}

Kuat tarik belah beton adalah nilai kuat tarik tidak langsung dari benda uji beton berbentuk silinder yang diperoleh dari hasil pembebanan benda uji yang diletakkan mendatar sejajar dengan permukaan meja penekan mesin uji. Nilai kuat tarik beton sebesar 10\% - 15\% dari kuat tekan beton.

$$
\mathrm{F}_{\mathrm{ct}}=\frac{2 \mathrm{P}}{\pi \mathrm{LD}}
$$

Dimana:

$\mathrm{F}_{\mathrm{C}_{\mathrm{t}}}=$ kuat tarik belah beton $\left(\mathrm{N} / \mathrm{mm}^{2}\right)$.

$\mathrm{P}=$ beban tekan maksimum saat silinder beton terbelah/runtuh $(\mathrm{N})$.

$\mathrm{L}=$ tinggi/panjang silinder beton (mm).

$\mathrm{D}=$ diameter silinder beton (mm).

\section{METODE PENELITIAN}

Metode eksperimen yang diterapkan dalam penelitian ini bertujuan untuk menyelidiki, membandingkan, dan membahas pengaruh lama pengeringan beton serat pandan pundak duri pada adukan beton sebesar $0.25 \%$, $0.5 \%$, dan $0.75 \%$ dari volume benda uji. Sampel di uji pada umur 34 hari dan 41 hari untuk melihat nilai kuat tarik belah dari masing-masing sampel. Pengujian kuat tarik belah beton dilakukan sebanyak 32 sampel dengan 4 sampel pada masing-masing variasi. Benda uji pada penelitian ini menggunakan cetakan silinder dengan ukuran diameter $15 \mathrm{~cm}$ dan tinggi $30 \mathrm{~cm}$. Benda uji silinder beton dirawat dengan direndam di dalam air bersih.

\section{Tahapan penelitian}

Tahapan penelitian melalui beberapa tahapan kerja yaitu :

1) Penelitian terhadap bahan dasar pembentuk beton. Tujuannya untuk mengetahui sifat dan karakteristik bahan-bahan tersebut.

2) Perhitungan perencanaan campuran beton, pencampuran beton, pengujian slump, pembuatan benda uji silinder serta perawatan benda uji selama proses pengikatan awal.

3) Pengujian kuat tarik belah benda uji berbentuk silinder.

\section{Prosedur penelitian}

Pengujian yang dilakukan adalah sebagai berikut :

1) Pengujian agregat kasar

2) Pengujian agregat halus

3) Pemeriksaan semen

4) Pemeriksaan serat pandan pundak duri

5) Perencanaan campuran beton (mix design)

6) Pengujian slump beton

7) Pengujian kuat tarik belah beton

\section{HASIL DAN PEMBAHASAN}

Pelaksanaan penelitian ini berupa pemeriksaan material, perencanaan adukan beton, pengadukan material campuran beton, pengujian slump, pencetakan benda uji, perawatan benda uji, dan pengujian kuat 
tarik belah. Hasil pemeriksaan material dapat dilihat pada Tabel 1 .

Tabel 1. Hasil Uji Fisis Material

\begin{tabular}{lccc}
\hline No & Jenis Pengujian & $\begin{array}{c}\text { Agregat } \\
\text { Halus }\end{array}$ & $\begin{array}{c}\text { Agregat } \\
\text { Kasar }\end{array}$ \\
\hline 1 & Berat Jenis & 2,38 & 2,70 \\
\hline 2 & Kadar Air (\%) & 2,83 & 2,35 \\
\hline 3 Kadar Lumpur (\%) & 3,30 & 3,25 \\
\hline 4 & Berat Isi $\left(\mathrm{kg} / \mathrm{dm}^{3}\right)$ & 1,4 & 1,44 \\
\hline 5 & $\begin{array}{c}\text { Modulus Halus } \\
\text { Butir }\end{array}$ & 1,93 & 6,98 \\
\hline
\end{tabular}

Hasil pengujian kuat tarik belah beton

Hasil pengujian kuat tarik beton normal dan beton variasi pundak duri sebagai bahan penambah pada adukan beton sebesar $0.25 \%$, $0.5 \%$, dan $0.75 \%$ diperoleh nilai kuat tarik yang berbeda-beda. Nilai kuat tarik belah beton variasi terhadap beton normal dapat dilihat pada Gambar 1.

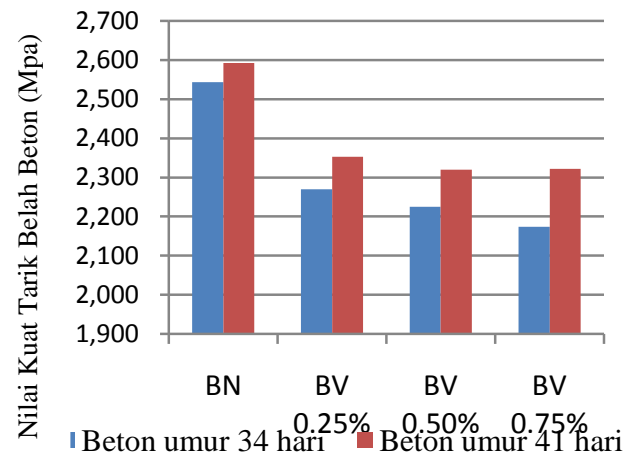

Gambar 1. Penurunan Nilai Kuat Tarik Belah Beton

Nilai kuat tarik belah yang diperoleh dari hasil pengujian beton variasi serat pandan pundak duri mengalami penurunan dari kuat tarik belah beton normal, tapi nilai kuat tarik belah beton untuk umur 41 hari menunjukkan peningkatan dari beton umur 34 hari. Serat pandan pundak duri pada beton juga menunjukkan banyak yang terputus pada saat pengujian. Kuat tarik belah pada beton variasi 0,75\% dengan beton variasi $0,5 \%$ menunjukkan perbedaan yang tidak terlalu signifikan yaitu sebesar
0,002. Selisih kuat tarik belah pada beton kemungkinan terjadi karena proses pembebanan beton. Persentase penurunan kuat tarik belah beton untuk pengaruh lama pengeringan menunjukkan bahwa kecenderungan untuk mendekati kuat tarik belah beton normal dapat dilihat pada Gambar 2. Retak yang terjadi pada beton dapat dilihat pada Gambar 3.

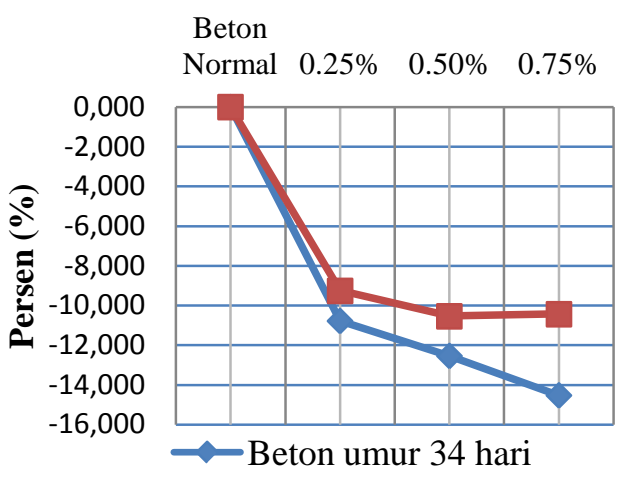

Gambar 2. Persentase Penurunan Nilai Kuat Tarik Belah Beton

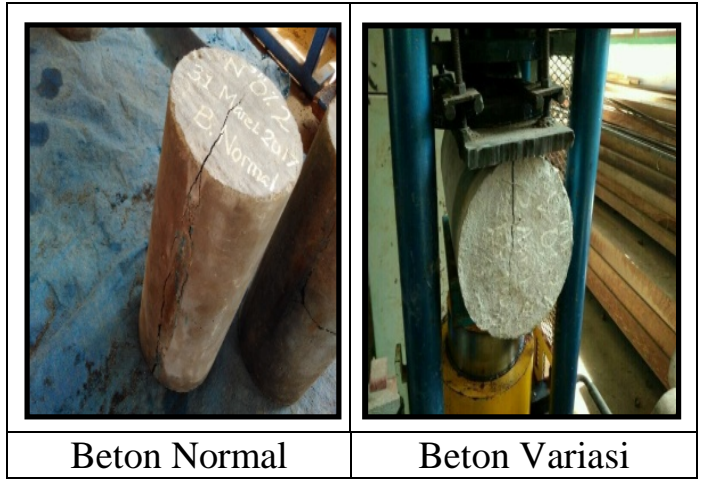

Gambar 3. Retak Pada Beton

\section{PENUTUP}

Kesimpulan yang dapat diambil dari hasil penelitian mengenai pengaruh lama pengeringan beton serat pandan pundak duri terhadap kuat tarik belah beton dengan agregat kasar ukuran maksimal $20 \mathrm{~mm}$ adalah sebagai berikut:

1) Kuat tarik belah beton dengan penambahan serat pandan pundak duri pada beton variasi mengalami penurunan terhadap kuat tarik belah beton normal. 
2) Kuat tarik belah beton yang didapat untuk umur 34 hari menunjukkan penurunan dengan variasi penambahan serat pandan pundak duri $0,25 \%, 0,5 \%$, dan $\quad 0,75 \%$ berturut-turut adalah $10,770 \%, \quad 12,532 \%$, dan $14,518 \%$ terhadap beton normal. Kuat tarik belah beton yang didapat untuk umur beton 41 hari menunjukkan penurunan dengan variasi penambahan serat pandan pundak duri 0,25\%, 0,5\%, dan 0,75\% berturut-turut adalah 9,249\%, 10,521\%, dan 10,423\% terhadap beton normal.

3) Kuat tarik belah beton yang menunjukkan penurunan terendah terjadi pada beton variasi $0,25 \%$ untuk umur beton 41 hari yaitu sebesar 2,353 MPa (9,249\%) terhadap beton normal. Kuat tarik belah beton yang menunjukkan penurunan tertinggi terjadi pada beton variasi $0,75 \%$ untuk umur 34 hari yaitu sebesar 2,174 MPa (14,518\%) terhadap beton normal.

\section{DAFTAR PUSTAKA}

Amna, K., Wesli, W. and Hamzani, H., 2017. Pengaruh Penambahan Serat Tandan Sawit terhadap Kuat Tekan dan Kuat Lentur Beton. Teras Jurnal, 4(2). pp.11-20.

Amri, S., 2005. Teknologi Beton. Yayasan John Hi-Tech Idetama. Jakarta.

Aulia, M.D., 2012. Studi Eksperimental Permeabilitas dan Kuat Tekan Beton K450 Menggunakan Zat Adiktif Conplast WP421. Teknik Sipil, 10. pp.211-222.

Han, J.S., 1998, April. Properties of nonwood fibers. In Proceedings of the
Korean society of wood science and technology annual meeting (pp. 3-12). Seoul, Korea: The Korean Society of Science and Technology.

Kemalasari, D. and wijayanti, I.T., 2008. Analisis Pengaruh Penambahan Serat Kawat Berkait pada Beton Mutu Tinggi Berdasarkan Optimasi Diameter Serat (The Analyze of The Influence of Adding Hooked Fibre to The High Strenght Concrete Based on Fibre Diameter Optimation) (Doctoral Dissertation, F. Teknik UNDIP).

Sari, R.A.I., Wallah, S.E. and Windah, R.S., 2015. Pengaruh Jumlah Semen dan Fas terhadap Kuat Tekan Beton dengan Agregat yang Berasal dari Sungai. Jurnal Sipil Statik, 3(1). pp.6876.

SNI 03-4810-1998. Metode Pembuatan dan Perawatan Benda Uji Beton di Lapangan, Departemen Pekerjaan Umum, Jakarta.

SNI 03-2049-2002. Semen Portland, Departemen Pekerjaan Umum, Jakarta.

SNI 03-2834-2002. Tata Cara Pembuatan Rencana Campuran Beton Normal, Departemen Pekerjaan Umum, Jakarta.

SNI 19-6728-2002. Penyusunan Neraca Sumber Daya-Bagian 1 : Sumber Daya Air Spasial, Departemen Pekerjaan Umum, Jakarta.

Suhardiman, M., 2011. Kajian Pengaruh Penambahan Serat Bambu Ori terhadap Kuat Tekan dan Kuat Tarik Beton. Jurnal Teknik, 1(2), pp.88-95.

Winarni, I. and Waluyo, T.K., 2006. Peningkatan Teknik Pengolahan Pandan (Bagian I): Pewarnaan dan Pengeringan. Journal of Chemical. pp. $1-21$. 